\title{
KAJIAN PERILAKU MENYIMPANG DI TEMPAT KERJA PADA PEGAWAI PERANGKAT DAERAH PROVINSI MALUKU
}

\author{
Novalien C. Lewaherilla \\ Universitas Pattimura Ambon, Jalan Jendral Ahmad Yani Nomor 9, Uritetu, \\ Sirimau, Poka, Tlk. Ambon, Kota Ambon, Maluku, Indonesia \\ (novalewaherilla@yahoo.com)
}

\begin{abstract}
ABSTRAK
Tujuan Penelitian ini adalah untuk menguji dan menganalisis pengaruh Iklim Etis terhadap perilaku menyimpang, pengaruh iklim etis terhadap spiritualitas di tempat kerja, pengaruh spiritualitas di tempat kerja terhadap perilaku menyimpang, pengaruh iklim etis terhadap perilaku menyimpang dengan dimediasi oleh spiritualitas di tempat kerja, pengaruh iklim etis terhadap komitmen organisasional, pengaruh komitmen organisasional terhadap perilaku menyimpang, pengaruh iklim etis terhadap perilaku menyimpang dengan dimediasi komitmen organisasional. Penelitian ini menggunakan pendekatan kuantitatif dengan metode analisis SEM PLS. Hasil penelitian menunjukan bahwa iklim etis dan komitmen organisasional berpengaruh terhadap perilaku menyimpang. Spiritualitas di tempat kerja tidak berpengaruh terhadap perilaku menyimpang.
\end{abstract}

Kata kunci: Iklim etis, spiritualitas di tempat kerja, komitmen organisasional, perilaku menyimpang

\begin{abstract}
The purpose of this study was to examine and analyze the influence of Ethical Climate on deviant behavior, the influence of ethical climate on spirituality in the workplace, the influence of spirituality in the workplace on deviant behavior, the influence of ethical climate on deviant behavior mediated by spirituality in the workplace, the influence of ethical climate towards organizational commitment, the influence of organizational commitment on deviant behavior, the influence of the ethical climate on deviant behavior and mediated organizational commitment. This study uses a quantitative approach with PLS SEM analysis method. The results showed that the ethical climate and organizational commitment influence deviant behavior. Spirituality at work does not affect deviant behavior.
\end{abstract}

Keywords: Ethical climate, workplace spirituality, organizational commitment, deviant behavior

\section{PENDAHULUAN}

Pemerintah Daerah merupakan

alat kelengkapan negara untuk mencapai cita-cita dan tujuan negara sebagaimana termaktub dalam

Pembukaan UUD Negara Republik 
Indonesia Tahun 1945 alinea ke-2 dan ke-4. Pemerintah Daerah sebagaimana dalam pasal 1 angka 2 Undang-undang Nomor 23 Tahun 2014 disebutkan sebagai penyelenggara urusan pemerintahan dan tugas pembantuan dengan prinsip otonomi seluas-luasnya dalam sistem dan prinsip Negara Kesatuan Republik Indonesia, sebagaimana dimaksud dalam Undang-Undang Dasar Negara Republik Indonesia Tahun 1945. Sebagai unsur penyelenggara pemerintahan daerah, maka pemerintah daerah memiliki hak untuk mengurus sendiri urusan pemerintahan sesuai dengan undangundang, sebagaimana yang terdapat dalam Undang-Undang Nomor: 23 Tahun 2014 pasal 1 angka 6 tentang Otonomi Daerah. Untuk melaksanakan otonomi daerah, maka di daerah-daerah otonomi dilengkapi dengan perangkat daerah. Sebagai aparatur Negara, Organisasi Perangkat Daerah (OPD) memiliki tugas penting dalam pelayanan publik kepada masyarakat. Dengan semakin meningkatnya tuntutan masyarakat akan kualitas pelayanan, maka fungsi pemerintah sebagai pelayan publik adalah untuk memenuhi kebutuhan penerima pelayanan maupun pelaksanaan ketentuan peraturan perundangundangan. Hakekat pelayanan publik adalah pemberian pelayanan prima kepada masyarakat yang merupakan perwujudan kewajiban aparatur pemerintah sebagai abdi masyarakat.

Sebagai pelayan publik (public servant), maka pegawai pada dinas daerah maupun badan daerah dituntut untuk melaksanakan nilainilai etika dan menciptakan iklim kerja yang etis dalam menyelenggarakan tugas pemerintahan. Berbicara tentang iklim etis, maka dalam Pasal 8,9 dan 10 Peraturan Pemerintah nomor 42 Tahun 2004 dikatakan bahwa Kode Etik Pegawai Negeri Sipil adalah pedoman sikap, tingkah laku, dan perbuatan Pegawai Negeri Sipil di dalam melaksanakan tugasnya dan pergaulan hidup sehari hari. Antara lain, Pegawai Negeri Sipil harus akuntan dalam melaksanakan tugas penyelenggaraan pemerintahan yang bersih dan berwibawa, tanggap, terbuka, jujur, dan akurat, tepat waktu dalam melaksanakan setiap kebijaksanaan dan program pemerintah, menggunakan atau memanfaatkan semua sumber daya negara secara efisien dan efektif. Selain itu pegawai negeri sipil harus melaksanakan tugas dan wewenang sesuai ketentuan yang berlaku; menjaga informasi yang bersifat rahasia; melaksanakan setiap kebijaksanaan yang ditetapkan oleh 
pejabat yang berwenang; membangun etos kerja untuk meningkatkan kinerja organisasi; patuh dan taat terhadap stdanar operasional dan tata kerja. Disamping itu, seorang pegawai negara sipil juga dituntut mengembangkan pemikiran secara kreatif dan inovatif dalam rangka peningkatan kinerja organisasi; berorientasi pada upaya peningkatan kualitas kerja, memberikan pelayanan dengan empati, hormat dan santun, tanpa pamrih dan tanpa unsur pemaksaan; memberikan pelayanan secara cepat, tepat, terbuka, dan adil serta tidak diskriminatif dan sebagainya.

Penerapan Iklim etis pada pegawai negeri sipil pada kenyataannya masih terdapat ketimpangan. Sikap kerja yang berhubungan dengan pelayanan kepada masyarakat masih bertentangan dengan standart etika PNS, juga aturan maupun undangundang kepegawaian yang berlaku sangat mempengaruhi terjadinya praktek-praktek penyimpangan di tempat kerja. Padahal sebagai pelayan publik maka fungsi pegawai negeri sipil adalah untuk memenuhi kebutuhan penerima pelayanan maupun pelaksana ketentuan peraturan perundang-undangan.

Organisasi publik (pemerintah) sebagai institusi yang membawa misi pelayanan publik, akhir-akhir ini semakin gencar mengkampanyekan dan saling berlomba untuk memberikan dan mengimplementasikan makna hakiki dari pelayanan publik tersebut, namun demikian di dalam pelaksanaannya masih jauh dari harapan yang diinginkan. Secara umum ada dua hal yang sangat berperan bagi organisasi pemerintah di dalam mengimplementasikan konsepsi mengenai pelayanan publik tersebut. Pertama adalah faktor komitmen untuk melaksanakan kebijakan yang sudah ada. Disini pemerintah daerah dituntut untuk mempunyai komitmen yang jelas melalui visi dan misi organisasi untuk melaksanakan fungsi pelayanan dengan baik. Kedua adalah faktor aparatur pelaksana (birokrat) yang menjalankan fungsi pelayanan tersebut. Dimana setiap individu yang menjalankan fungsi pelayanan harus mengacu pada komitmen organisasional yang telah dituangkan di dalam visi dan misi organisasi tersebut.

Perilaku pelayan publik juga erat kaitannya dengan norma dan nilai yang diyakini dalam suatu organisasi. Budaya menjadi elemen penting dalam perilaku karyawan, merancang ulang norma, attitude dan nilai sosial merupakan hal penting 
yang harus dilakukan suatu organisasi untuk mengatasi permasalahan deviant workplace behavior (Appelbaum, 2006). Normanorma tersebut adalah kebijaksanaan yang melarang perilaku-perilaku tertentu, seperti mencuri. tetapi norma-norma tersebut juga bisa merupakan peraturan tidak tertulis (Robbins, 2008). Nilai psikologi lainnya seperti spiritualitas di tempat kerja akan menjadi semakin berkontribusi bagi pegawai perangkat daerah dalam berperilaku. Spiritualitas di tempat kerja (Workplace Spirituality) menurut Miliman et al. (2006) adalah pemahaman karyawan yang melihat diri mereka sebagai makhluk spiritual yang membutuhkan pengasuhan jiwa yang mengalami rasa, tujuan, makna dan keterikatan satu dengan yang lan.

Secara teoritis, perilaku menyimpang (workplace deviance) didefinisikan sebagai suatu perilaku yang sengaja dilakukan dan bertentangan dengan norma-norma yang berlaku dalam organisasi sehingga dapat mengancam keberlangsungan organisasi atau anggota, atau bahkan keduanya (Bennett dan Robinson, 2000). Basis filosofi yang dapat digunakan untuk menjelaskan adanya perilaku menyimpang adalah teori kontrak psikologis (psychological contract). Teori kontrak psikologis dapat didefinisikan sebagai suatu kondisi dimana ada kesepahaman timbalbalik antara seseorang dengan organisasi, Vantilborgh et al. (2012)

Ada dua bentuk perilaku menyimpang berdasarkan masingmasing antesedennya yaitu interpersonal dan (2) organisasional. Penyimpangan interpersonal merupakan tipe yang disebabkan oleh perbedaan karakteristik anggota dalam suatu organisasi, sedangkan jenis penyimpangan organisasional muncul sebagai akibat dari faktorfaktor organisasi atau konteks, Berry et al.(2007); Hershcovis et al.(2007); Lee dan Allen, 2002; Chen et al.( 2015). Perilaku menyimpang memberikan pengaruh yang negatif bagi keberlangsungan organisasi. Dalam konteks organisasi pemerintah, perilaku menyimpang dapat menyebabkan munculnya ketidakpercayaan (mistrust) publik, hilangnya sumberdaya ekonomi, tidak tercapainya tujuan pembangunan yang telah ditetapkan pemerintah dan bahkan berdampak pada pertumbuhan PDB maupun tenaga kerja. Robinson dan Bennet (1997) menjelaskan bahwa deviant behavior seringkali menghasilkan suatu kejadian spesifik yang memicu seseorang untuk bertindak. Kejadian- 
kejadian spesifik tersebut dapat berupa tekanan finansial, tekanan sosial, perlakuan yang tidak adil, kemiskinan, perubahan organisasional, atau tekanan lainnya untuk menyebabkan seorang anggota merasa berbeda dari kondisi yang umum. Kondisi inilah yang menyebabkan munculnya perilakuperilaku negatif di tempat kerja.. Adejoh dan Adejoh menjelaskan bahwa pelayan publik seringkali memperlihatkan perilaku menyimpang sehingga menimbulkan rasa tidak nyaman bagi masyarakat. Fagbohungbe et al.(2012) juga merangkum hasil-hasil riset dan menyebutkan bahwa perilaku negatif yang sering muncul adalah perilaku agresif seperti berbohong, menyebarkan rumor, tidak mau berusaha dan ketidakhadiran. Perilaku-perilaku negatif tersebut sangat bertentangan dengan normanorma organisasi dan merupakan jenis perilaku antisosial.

Salah satu daerah di Indonesia yang terus berupaya meningkatkan kualitas pelayanan publik adalah Propinsi Maluku. Secara umum, ada 11 kabupaten/kota yang berada di wilayah Propinsi Maluku. Dalam penyelenggaraan pemerintahan, fenomena perilaku menyimpang di tempat kerja juga sering ditemukan di berbagai satuan kerja perangkat daerah yang ada di kabupaten/kota maupun di tingkat pemerintah Propinsi Maluku. Berdasarkan survei awal bahwa kecenderungan pelanggaran pegawai masih banyak dilakukan mulai pelanggaran yang kecil seperti terlambat masuk kerja, pulang lebih awal atau masuk tanpa ijin, bekerja tidak maksimal, bolos dan santai di luar pada jam kantor, sampai kasus penyimpangan seksual dan perilaku yang merugikan organisasi seperti menggunakan dana-dana negara karena pola hidup komsumtif bahkan sehingga tidak sedikit karyawan ataupun pejabat pemerintahan yang terlibat kasus manipulasi dan korupsi. Hal ini sangat mempengaruhi kinerja pelayanan publik. Perilaku-perilaku menyimpang tersebut menyebabkan kerugian ekonomis maupun menghambat upaya peningkatan pelayanan publik. Dengan demikian, diperlukan riset dengan pembuktian model konseptual yang dapat menjelaskan fenomena perilaku menyimpang pada pemerintah daerah kabupaten/kota di Propinsi Maluku. Harapannya, model konseptual yang diajukan dapat dijadikan pedoman dalam melakukan reformasi birokrasi dengan peningkatan kapasitas aparatur sipil negara. Dengan demikian, upaya pembangunan dan pelayanan publik dapat dilakukan 
dengan baik untuk kesejahteraan masyarakat.

\section{TELAAH LITERATUR DAN}

\section{PERUMUSAN HIPOTESIS}

\section{Iklim Etis (Ethical Climate)}

Iklim etis (ethical climate) atau iklim kerja yang beretika adalah konsep yang tentang perilaku yang benar san salah di tempat kerja yang mencerminkan nilai dari organisasi yang sebenarnya dan membentuk pengambilan keputusan yang etis bagi para anggotanya (Robbins S.P, 2015). Iklim etis merupakan konsep yang berkembang sebagai bagian dari iklim organisasi dimana iklim organisasi (organizational climate) adalah persepsi yang dimiliki para anggota organisasi mengenai organisasi dan lingkungan kerja mereka. Iklim etis merupakan bagian dari iklim organisasi yang mempengaruhi perilaku dan kinerja anggota organisasi artinya iklim yang beretika mencerminkan nilai dari organisasi yang sebenarnya dan membentuk pengambilan keputusan yang etis baga para anggotanya. Iklim etis adalah suatu persepsi atau pandangan yang berlaku dalam praktek dan prosedur organsiasi yang memiliki konten etis.

Praktik etis dalam organisasi kemudian dikembangkan oleh Appelbaum et al.(2005) dengan menyatakan bahwa iklim etis organisasi memberi kontribusi yang signifikan terhadap hubungan kerja dan pembentukan perilaku yang baik karena iklim etis organisasi merupakan seperangkat nilai dan norma yang dapat membimbing tindakan karyawan. Iklim etis organisasi dapat mendorong terciptanya perilaku yang etis dan sebaliknya juga dapat mendorong terciptanya perilaku yang tidak etis dalam organisasi sehingga akan menyebabkan terjadinya menyimpang etis dan perilaku di tempat kerja yang dapat mempengaruhi perilaku berbagi pengetahuan

\section{Spiritualitas di Tempat kerja (Workplace Spirituality)}

Workplace spirituality adalah konsep baru dalam model manajemen dan perilaku organisasi. Konsep ini pun sebenarnya telah digambarkan dalam konsep-konsep perilaku organisasi seperti values, ethics, dan sebagainya. Hal ini dijelaskan oleh Robbins (2005) sebagai berikut: The concept of workplace spirituality draws on our previous discussion of topics such as values, ethics, motivation, leadership and work/life balance. Namun, spiritualitas menggabungkan keseluruhan pembahasan tersebut secara holistic dan utuh. Istilah yang biasanya digunakan untuk menjelaskan konsep ini adalah 
workplace spirituality, spirituality in the workplace, spirituality at work, spiritual workplace, spirit at work atau spiritualitas kerja. Istilah spiritualitas yang dimaksud merujuk pada sesuatu yang universal, yaitu meaning, purpose, dan value. Robbins (2005) mendefinisikan workplace spirituality sebagai berikut,

"Workplace spirituality
recognizes that people have an
inner life that nourishes and is
nourished by meaningful work
that takes place in the context
of community. Organizations
that promote a spiritualcult
recognize that people have
both mind and a spirit, seek to
find meaning and purpose in
their work, and desire to
connect with other human
beingand be part of
community".

Pemahaman lain mengenai konsep ini dijabarkan oleh Sauber (2013) sebagai berikut,

"Spirit in the workplace is leaders learning to lead instead of manage. It is an understanding that organizations are in service, not just providing a service. It is searching one's self for his/her purpose in life and tapping into that passion. It is embracing and appreciating the gifts and talents each and every employee brings to their job each and every day day in and day out."

$\begin{array}{lr}\text { Penggunaan istilah } & \text { spiritual } \\ \text { tidak berkaitan dengan } & \text { agama } \\ \text { instusional. Spiritualitas } & \text { adalah }\end{array}$

kapasitas bawaan dari otak manusia spiritualitas berdasarkan struktur struktur dari dalam otak yang memberi kita kemampuan dasar untuk membentuk makna, nilai, dan keyakinan. Spiritualitas bersifat prakultural dan lebih primer dibandingkan dengan agama. Karena kita punya kecerdasan spirituallah, umat manusia kemudian menganut dan menjalankan sistem keagamaan sebagai jawaban atas pertanyaanpertanyaan yang diajukan oleh spiritualitas (Zohar dan Marshall, 2005). Dapat disimpulkan bahwa spiritualitas memberikan nilai-nilai yang dapat dipahami dan dipegang bersama dan agama memberikan jalan untuk pelaksanaannya di tingkat individu sesuai dengan ajarannya masing-masing. Khusus di dunia bisnis, spiritualitas harus mendorong lahirnya generasi ketiga (Pradiansyah, 2007).

Ada tiga aspek utama workplace spirituality (Milliman et al., 2003), yaitu Purpose in one's work atau "meaningful work", having a "sense of community", dan being in "alignment with the organization's values" and mission. Masing-masing aspek tersebut mewakili tiga level dari workplace spirituality, yaitu individual level, group level dan organizational level. 
Komitmen

Organizational

(Organizational Commitment)

Komitmen merupakan term yang memiliki makna yang cukup luas dan banyakmendapat perhatian dalam konteks organisasi maupun sosiologis. Tidak hanya itu, Yoon dan Thye (2002) menjelaskan bahwa dalam beberapa tahun terakhir, teori tentang komitmen semakin diperluas melalui berbagai penelitian dalam bidang pergerakan sosial (social movement) relasi timbal-balik secara sosial (social exchange relations) dan lebih umum lagi yaitu solidaritas dan keteraturan sosial. Secara teoritis, defenisi-defenisi tentang komitmen lebih banyak difokuskan pada ikatan psikologis individu dengan objek tertentu. Wong dan Tong (2014) menjelaskan bahwa seseorang akan memutuskan untuk tetap berada dalam suatu organisasi sepanjang ada kemungkinan terjadinya tukarmenukar nilai dengan organisasi yang tidak terjadi di tempat lain. Preskripsi tersebut juga tergambar dari defenisidefenisi tentang komitmen.

Luthans (2006) mengemukakan bahwa ukuran definisi komitmen organisasisional seringkali didefinisikan sebagai: (1) keinginan kuat untuk tetap menjadi anggota sebuah organisasi tertentu, kemauan untuk menggunakan segala usaha atas nama organisasi, keyakinan yang kuat dan penerimaan atas nilai dan tujuan organisasi. Dengan kata lain, sikap-sikap tersebut merefleksikan kesetiaan karyawan terhadap organisasi mereka dan merupakan proses terus menerus dimana partisipasi organisasi mengekspresikan perhatian mereka pada organisasi dan keberhasilan serta kelangsungan hidupnya.

Defenisi yang dikemukakan oleh Moynihan dan Pandey (2007), komitmen organisasi sebagai kewajiban normatif terhadap organisasi, yang merefleksikan loyalitas dan keengganan untuk meninggalkan organisasi. Berdasarkan defenisi tersebut, komitmen organisasi memiliki 3 komponen dasar, yaitu (1) keyakinan kuat dan peneritaan terhadap nilai dan tujuan organisasi (identifikasi); (2) keinginan untuk memperlihatkan usaha maksimal untuk kepentingan organisasi (keterlibatan), dan (3) dorongan yang kuat untuk tetap berada dalam organisasi (loyalitas). Dimensi yang serupa juga dikemukakan oleh Cohen (2003) bahwa komitmen memiliki 3 dimensi yaitu identifikasi, afiliasi dan keterlibatan moral.

\section{Perilaku Menyimpang (Deviant Behavior)}

Perilaku menyimpang di tempat kerja (workplace deviance) telah 
menjadi fenomena umum dan menjadi konsep sentral baik dalam konteks teoritis maupun analisis empiris selama 3 dekade terakhir, Chen et al. (2015); Thau et al. (2009); Ferris et al. (2009). Tema ini memunculkan berbagai perdebatan dan menjadi pertimbangan dalam berbagai sudut pandang yang berbeda. Sejauh ini, konsep perilaku menyimpang lebih banyak dipelajari berkaitan dengan konteks manajemen karena menimbulkan konsekuensi kerugian biaya yang tinggi maupun hilangnya kenyamanan bekerja dalam organisasi, Chen et al. (2015).

Hasil studi awal yang dilakukan oleh Harper (1990) menemukan bahwa 33 sampai 75 persen pekerja di Amerika pernah atau sering melakukan pencurian, sabotase, agresi personal serta ketidakhadiran yang tidak disertai pemberitahuan resmi. Bashir et al. (2012) juga menemukan bahwa 82 persen pekerja pada organisasi publik di Pakistan sering masuk kantor terlambat, 90 persen menggunakan waktu makan siang yang lebih lama dan 66 persen pekerja sering pulang kantor sebelumnya. Menurut Cheang dan Appelbaum (2015), ketidakhadiran di tempat kerja menyebabkan kerugian sebesar 40 milliar dolar setiap tahunnya di Amerika Serikat, Faktafakta yang dikemukakan telah memicu berbagai penelitian untuk menganalisis perilaku menyimpang.

Fernandez and Moldogaziev (2011) menjelaskan bahwa permbedayaan pekerja merupakan salah satu tema sentral dalam konteks reformasi manajerial di Amerika Serikat saat ini. Asumsinya didasarkan pada National Performance Review (NPR) yang menyebutkan bahwa ada kecendrungan penurunan kinerja pemerintah. Hal ini tergambar dari sikap pekerja sektor publik malas bahkan tidak berkompeten yang ditambah dengan sistem yang kaku serta menghambat kreativitas dan inovasi (Thompson, 2000). Dugaan tersebut diperkuat dengan hasil-hasil riset yang memperlihatkan bahwa perilaku-perilaku yang buruk lebih cenderung terjadi pada organsiasi publik dibanding swasta (Aquino et al., 2006; Mayhewand McCarthy, 2005).

Meskipun didefenisikan secara berbeda, perilaku-perilaku tersebut menimbulkan dampak negatif bagi individu maupun performa organisasi secara umum (Muafi, 2011) serta dapat pula memicu keinginan anggota untuk keluar, ketidakpuasan, penurunan wibawa organisasi, pencurian dll (Bollin dan Heatherly, 2001). Zribi dan Souai (2013) menjelaskan bahwa ada 3 prinip esensial yang dapat digunakan untuk 
mengkarakterisasi perilaku menyimpang. Pertama, perilaku menyimpang membawa dampak merusak secara sistematis terhadap organisasi. Kedua, bahwa perilakuperilaku tersebut haruslah dilakukan secara sadar dan bukan suatu kebetulan. Artinya, individu yang berperilaku menyimpang secara sadar melawan norma-norma yang telah ditetapkan oleh organisasi. Ketiga, perilaku tersebut dilakukan secara langsung terhadap organisasi (sabotase) atau secara tidak langsung (kekerasan verbal, fisik dan moral serta gangguan seksual).

Perilaku menyimpang di tempat kerja terdiri penyimpang interpersonal dan penyimpangan organisasional. Perilaku menyimpang juga bersifat positif atau membangun (konstruktif) dimana pekerja mengikutsertakan perilaku inovatif yang memberikan organisasi dengan kreativitas penting, dan bersifat negatif yakni termasuk ketidakpatuhan pada pengarahan yang sifatnya disfungsional. Penyimpangan positif atau penyimpangan konstruktif (constructive deviance) didefinisikan sebagai perilaku yang melanggar norma-norma organisasi dengan maksud untuk membantu organisasi (Galperin dalam Appelbaum et al., 2007). Penyimpangan konstruktif dapat mencangkup perilaku yang belum disahkan yang menfasilitasi tujuan organisasi.

Olabimitan dan Alausa (2014) juga mengemukakan bahwa ada dua cara perilaku menyimpang di tempat kerja dapat dibedakan dari perilaku lainnya, yaitu 1) volitional: perilaku atas kemauan sendiri dan 2) memiliki tujuan yang berbahaya.

Berdasarkaan Latar Belakang dan kajian teori, maka hipotesis yang dibangun adalah:

H1: Iklim etis berpengaruh terhadap perilaku menyimpang

H2: Iklim etis berpengaruh terhadap spiritualitas di tempat kerja

H3: Spiritualitas di tempat kerja berpengaruh terhadap perilaku menyimpang

H4: Spiritualitas tempat kerja memediasi pengaruh iklim etis terhadap perilaku menyimpang

H5: Iklim etis berpengaruh terhadap komitmen organisasional

H6: Komitmen organisasional berpengaruh terhadap perilaku menyimpang

H7: Komitmen organisasional memediasi pengaruh iklim etis terhadap perilaku menyimpang

\section{METODE}

Penelitian ini termasuk jenis penelitian explanatory dengan 
pendekatan kuantitatif . Penelitian ini dilakukan pada pegawai Perangkat Daerah di Provinsi Maluku. Secara umum, ada 11 kabupaten/kota yang ada di Propinsi Maluku. Populasi dalam penelitian ini adalah pegawai negeri sipil (PNS) dengan eselon 2B, 3A dan 3B pada Dinas Daerah dan Badan Melalui teknik Multi Stage Sample, maka sampel penelitian yang dipilih adalah Pegawai Dinas dan Badan Daerah dengan eselon 2B,3A dan 3B pada Kabupaten Maluku Tenggara Barat (MTB), Kabupaten Buru, Kabupaten Seram Bagian Barat (SBB) dan Kota Ambon.

Pengumpulan data dilakukan dengan cara menyebar kuesioner. Selain itu teknik wawancara dilakukan dengan cara deep interview yaitu menggali informasi yang lebih rinci tentang variabel yang diteliti secara terbuka. Data yang terkumpul dianalisis dengan menggunakan statistik deskriptif dan inferensial. Analisis deskriptif digunakan untuk menjelaskan/mendiskripsikan karakeristik masing-masing variabel yang diteliti. Analisis inferensi dengan menggunakan statistik structure equation model dengan Smart PLS 5.0 .
HASIL DAN PEMBAHASAN

Validitas dan Reliabilitas Konstruk

Pemeriksaan validitas dan reliabilitas konstruk dilakukan sejumlah cara. Pengujian ini dilakukan untuk menilai validitas konvergen, validitas diskriminan, dan reliabilitas. Suatu model memiliki validitas konvergen apabila nilai outer loading $>0,7$, communality $>0,5$, dan average variance extracted (AVE) > 0,5. Namun, model pengukuran dengan nilai outer loading 0,5 sampai dengan 0,6 dianggap cukup untuk penelitian yang bersifat eksploratori (Ghozali, 2008).

Hasil pengujian outer model yang bersifat reflektif menunjukkan bahwa seluruh item memiliki outer loading lebih dari 0,50. Selain uji validitas, suatu model pengukuran dikatakan baik apabila memiliki tingkat reliabilitas yang cukup.Reliabilitas menunjukkan tingkat akurasi, konsistensi, dan ketepatan suatu alat ukur dalam melakukan pengukuran.

Suatu konstruk dikatakan reliabel jika nilai koefisien cronbach's alpha lebih besar dari 0,70, tetapi nilai 0,60 masih dapat diterima untuk penelitian yang bersifat eksploratori (Hartono dan Abdillah, 2009; Hair et al., 2010). 
Tabel 1. Loading Factor

\begin{tabular}{|c|c|c|c|}
\hline Variabel & Indikator & Item & $\begin{array}{l}\text { Loading } \\
\text { Factor }\end{array}$ \\
\hline \multirow[t]{10}{*}{ Iklim Etis } & \multirow[t]{2}{*}{ Kepedulian } & IE.1 & 0,852 \\
\hline & & IE.2 & 0,877 \\
\hline & \multirow[t]{3}{*}{ Hukum Etis } & IE. 3 & 0,863 \\
\hline & & IE.4 & 0,831 \\
\hline & & IE. 5 & 0,751 \\
\hline & \multirow[t]{2}{*}{ Aturan } & IE.6 & 0,923 \\
\hline & & IE.7 & 0,916 \\
\hline & Pemgutamaan & IE. 8 & 1,000 \\
\hline & \multirow{2}{*}{ Kebebasan } & IE. 9 & 0,908 \\
\hline & & IE. 10 & 0,722 \\
\hline \multirow[t]{9}{*}{ Spiritualitas di tempat kerja } & \multirow[t]{2}{*}{ Memaknai kerja } & SP.1 & 0,902 \\
\hline & & SP.2 & 0,887 \\
\hline & \multirow[t]{3}{*}{ Perasaan kebersamaan } & SP.3 & 0,827 \\
\hline & & SP.4 & 0,720 \\
\hline & & SP. 5 & 0,894 \\
\hline & \multirow[t]{2}{*}{ Kesamaan Nilai } & SP.6 & 0,889 \\
\hline & & SP.7 & 0,736 \\
\hline & \multirow[t]{2}{*}{ Kehidupan Batin } & SP.8 & 0,726 \\
\hline & & SP.9 & 0,872 \\
\hline \multirow[t]{7}{*}{ Komitmen Organisasional } & \multirow[t]{2}{*}{ Afektif } & KO.1 & 0,921 \\
\hline & & KO.2 & 0,911 \\
\hline & \multirow{2}{*}{ Normatif } & KO.3 & 0,896 \\
\hline & & $\mathrm{KO} .4$ & 0,886 \\
\hline & \multirow[t]{3}{*}{ Berkelanjutan } & KO. 5 & 0,780 \\
\hline & & KO.6 & 0,868 \\
\hline & & KO.7 & 0,847 \\
\hline \multirow[t]{13}{*}{ Perilaku Menyimpang } & \multirow[t]{5}{*}{ Individu } & PMI.1 & 0,862 \\
\hline & & PMI.2 & 0,902 \\
\hline & & PMI.3 & 0,833 \\
\hline & & PMI.4 & 0,655 \\
\hline & & PMI.5 & 0,806 \\
\hline & \multirow[t]{8}{*}{ Organisasi } & PMO. 1 & 0,722 \\
\hline & & PMO.2 & 0,778 \\
\hline & & PMO.3 & 0,782 \\
\hline & & PMO.4 & 0,798 \\
\hline & & PMO.5 & 0,770 \\
\hline & & PMO.6 & 0,766 \\
\hline & & PMO. 7 & 0,756 \\
\hline & & PMO. 8 & 0,824 \\
\hline
\end{tabular}

Sumber : Hasil Olahan Data (2017)

Reliabilitas model pengukuran juga dapat dinilai dari besar koefisien composite reliability, termasuk dalam kategori baik apabila koefisien ini mencapai 0,70 atau lebih. Dua cara lain dalam menilai reliabililitas adalah koefisien average variance extracted (AVE) dan communality, termasuk dalam kategori baik apabila koefisien ini mencapai 0,50 atau lebih. Koefisien AVE akan mempunyai nilai yang sama persis dengan 
communality. Hasil pengujian reliabilitas menunjukkan bahwa semua konstruk memiliki koefisien cronbach's alpha lebih dari 0,60, koefisien composite reliability lebih dari 0,70, serta koefisien AVE dan communality lebih dari 0,50. Dengan demikian, semua model pengukuran yang digunakan dalam penelitian ini sudah mempunyai reliabilitas yang tinggi.

Hasil pengujian outer model yang bersifat reflektif menunjukkan bahwa seluruh item memiliki outer loading lebih dari 0,50. Selain uji validitas, suatu model pengukuran dikatakan baik apabila memiliki tingkat reliabilitas yang cukup.Reliabilitas menunjukkan tingkat akurasi, konsistensi, dan ketepatan suatu alat ukur dalam melakukan pengukuran. Suatu konstruk dikatakan reliabel jika nilai koefisien cronbach's alpha lebih besar dari 0,70 , tetapi nilai 0,60 masih dapat diterima untuk penelitian yang bersifat eksploratori (Hartono dan Abdillah, 2009; Hair et al., 2010). Reliabilitas model pengukuran juga dapat dinilai dari besar koefisien composite reliability, termasuk dalam kategori baik apabila koefisien ini mencapai 0,70 atau lebih. Dua cara lain dalam menilai reliabililitas adalah koefisien average variance extracted (AVE) dan communality, termasuk dalam kategori baik apabila koefisien ini mencapai 0,50 atau lebih. Koefisien AVE akan mempunyai nilai yang sama persis dengan communality. Hasil pengujian reliabilitas menunjukkan bahwa semua konstruk memiliki koefisien cronbach's alpha lebih dari 0,60, koefisien composite reliability lebih dari 0,70, serta koefisien AVE dan communality lebih dari 0,50. Dengan demikian, semua model pengukuran yang digunakan dalam penelitian ini sudah mempunyai reliabilitas yang tinggi.

Selain memenuhi validitas konvergen, suatu model pengukuran harus memiliki validitas diskriminan. Suatu model pengukuran memenuhi validitas diskriminan apabila akar AVE suatu konstruk lebih besar dibandingkan koefisien korelasi dengan konstruk lainnya. Sebagai contoh, konstruk kepedulian mempunyai koefisien AVE sebesar 0,748 maka didapatkan akar AVE sebesar 0,865. Besar koefisien korelasi konstruk kepedulian dengan konstruk lainnya berkisar -0,232 0,684 sehingga analisis ini memberikan kesimpulan adanya dicriminant validity yang baik. 
Tabel 2. Hasil Validitas Konvergen

\begin{tabular}{lccc}
\hline Konstruk & $\begin{array}{c}\text { Koefisien Alpha } \\
\text { Cronbach }\end{array}$ & $\begin{array}{c}\text { Composite } \\
\text { Reliability }\end{array}$ & AVE \\
\hline Iklim Etis & & & \\
Kepedulian & 0.663 & 0.856 & 0.748 \\
Hukum Etis & 0.747 & 0.856 & 0.666 \\
Aturan & 0.817 & 1.000 & 0.845 \\
Pengutamaan & 1.000 & 0.803 & 1.000 \\
Kebebasan & 0.636 & & 0.673 \\
Spiritualitas & & 0.889 & \\
Memaknai kerja & 0.750 & 0.856 & 0.800 \\
Perasaan kebersamaan & 0.747 & 0.798 & 0.667 \\
Kesamaan Nilai & 0.611 & 0.782 & 0.644 \\
Kehidupan Batin & 0.659 & 0.912 & 0.839 \\
Komitmen Organisasi & & 0.885 & 0.794 \\
Afektif & 0.808 & 0.871 & 0.693 \\
Normatif & 0.740 & & \\
Berkelanjutan & 0.780 & 0.908 & 0.666 \\
& & 0.923 & 0.601 \\
Perilaku menyimpang & 0.871 & & \\
Individu & 0.905 & &
\end{tabular}

Sumber: Hasil Olahan Data (2017)

Hasil pengujian menunjukkan

nilai akar AVE suatu variabel lebih tinggi jika dibandingkan nilai korelasi antar variabel. Dengan demikian dapat disimpulkan bahwa model pengukuran penelitian ini telah memenuhi validitas diskriminan. Dalam berbagai sudut penilaian yang dilakukan pada validitas dan reliabilitas konstruk didapatkan kesimpulan seluruh item pertanyaan dapat digunakan sebagai pengukur variabel dalam penelitian ini.

\section{Kecocokan Model}

Kecocokan model dapat dinilai dari koefisien determinasi model $\left(\mathrm{R}_{\mathrm{m}}{ }^{2}\right)$. Koefisien determinasi model dihitung dengan menggunakan seluruh koefisien determinasi $\left(\mathrm{R}^{2}\right)$ yang ada di dalam model. Hasil perhitungan $\mathrm{R}^{2}$ dapat dilihat pada Tabel 5.20. Nilai $R^{2}$ untuk variabel spiritualitas di tempat kerja adalah 0,269. Nilai tersebut menunjukkan bahwa variasi spiritualitas di tempat kerja yang dijelaskan oleh iklim etis sebesar 26,9\%, sedangkan sisanya dijelaskan oleh variabel lain. Nilai $\mathrm{R}^{2}$ untuk variabel komitmen organisasi adalah 0,384. 
Tabel 3.Hasil Perhitungan Discriminant Validity

\begin{tabular}{|c|c|c|c|c|c|c|c|}
\hline Konstruk & AVE & \multicolumn{2}{|c|}{ Kepedulian } & $\begin{array}{c}\text { Hukum } \\
\text { Etis }\end{array}$ & Aturan & $\begin{array}{l}\text { Penguta- } \\
\text { maan }\end{array}$ & Kebebasan \\
\hline Kepedulian & 0.748 & \multicolumn{2}{|c|}{$(0,865)$} & 0,684 & 0,559 & 0,391 & 0,349 \\
\hline Hukum Etis & 0.666 & \multicolumn{2}{|c|}{0,684} & $(0,816)$ & 0,699 & 0,557 & 0,398 \\
\hline Aturan & 0.845 & \multicolumn{2}{|c|}{0,559} & 0,699 & $(0,919)$ & 0,536 & 0,286 \\
\hline Pengutamaan & 1.000 & \multicolumn{2}{|c|}{0,391} & 0,557 & 0,536 & $(1,000)$ & 0,315 \\
\hline Kebebasan & 0.673 & \multicolumn{2}{|c|}{0,349} & 0,398 & 0,286 & 0,315 & $(0,820)$ \\
\hline Makna & 0.800 & \multicolumn{2}{|c|}{0,404} & 0,417 & 0,378 & 0,264 & 0,267 \\
\hline Perasaan & 0.667 & 0,395 & & 0,400 & 0,394 & 0,274 & 0,306 \\
\hline Kesamaan & 0.665 & \multicolumn{2}{|c|}{0,298} & 0,297 & 0,331 & 0,207 & 0,296 \\
\hline Kehidupan & 0.644 & 0,328 & & 0,358 & 0,330 & 0,438 & 0,235 \\
\hline Afektif & 0.839 & 0,523 & & 0,457 & 0,325 & 0,349 & 0,300 \\
\hline Normatif & 0.794 & \multicolumn{2}{|c|}{0,280} & 26 & 0,313 & 0,336 & 0,161 \\
\hline Berkelanjutan & 0.693 & 0,30 & & 78 & 0,298 & 0,195 & 0,251 \\
\hline Individu & 0.666 & $-0,23$ & -0 , & 33 & $-0,256$ & $-0,287$ & $-0,229$ \\
\hline Organisasi & 0.601 & $-0,2$ & -0 , & 53 & $-0,264$ & $-0,316$ & $-0,266$ \\
\hline Konstruk & AVE & Mak & Per & asaan & Kesam & $\operatorname{aan}$ & Kehidupan \\
\hline Kepedulian & 0.748 & 0,40 & & 395 & 0,29 & & 0,328 \\
\hline Hukum Etis & 0.666 & 0,41 & & 400 & 0,29 & & 0,358 \\
\hline Aturan & 0.845 & 0,37 & & 394 & 0,33 & & 0,330 \\
\hline Pengutamaan & 1.000 & 0,26 & & 274 & 0,20 & & 0,438 \\
\hline Kebebasan & 0.673 & 0,26 & & 306 & 0,29 & & 0,235 \\
\hline Makna & 0.800 & $(0,89$ & & 697 & 0,51 & & 0,409 \\
\hline Perasaan & 0.667 & $0,6 \mathrm{c}$ & & 817) & 0,50 & & 0,547 \\
\hline Kesamaan & 0.665 & 0,51 & & 506 & $(0,81$ & 5) & 0,453 \\
\hline Kehidupan & 0.644 & 0,40 & & 547 & 0,45 & & $(0,802)$ \\
\hline Afektif & 0.839 & $0,4 \varepsilon$ & & 482 & 0,42 & & 0,420 \\
\hline Normatif & 0.794 & 0,42 & & 478 & 0,30 & & 0,341 \\
\hline Berkelanjutan & 0.693 & 0,21 & & 357 & 0,27 & & 0,256 \\
\hline Individu & 0.666 & $-0,2$ & & 287 & $-0,24$ & & $-0,202$ \\
\hline Organisasi & 0.601 & $-0,3$ & & 348 & $-0,24$ & 47 & $-0,238$ \\
\hline Konstruk & AVE & Afektif & Normatif & Berk & celanjutan & Individu & Organisasi \\
\hline Kepedulian & 0.748 & 0,523 & 0,280 & & 0,307 & $-0,232$ & $-0,244$ \\
\hline Hukum Etis & 0.666 & 0,457 & 0,326 & & 0,378 & $-0,333$ & $-0,353$ \\
\hline Aturan & 0.845 & 0,325 & 0,313 & & 0,298 & $-0,256$ & $-0,264$ \\
\hline Pengutamaan & 1.000 & 0,349 & 0,336 & & 0,195 & $-0,287$ & $-0,316$ \\
\hline Kebebasan & 0.673 & 0,300 & 0,161 & & 0,251 & $-0,229$ & $-0,266$ \\
\hline Makna & 0.800 & 0,481 & 0,429 & & 0,215 & $-0,241$ & $-0,300$ \\
\hline Perasaan & 0.667 & 0,482 & 0,478 & & 0,357 & $-0,287$ & $-0,348$ \\
\hline Kesamaan & 0.665 & 0,428 & 0,302 & & 0,271 & $-0,243$ & $-0,247$ \\
\hline Kehidupan & 0.644 & 0,420 & 0,341 & & 0,256 & $-0,202$ & $-0,238$ \\
\hline Afektif & 0.839 & $(0,916)$ & 0,572 & & 0,534 & $-0,400$ & $-0,378$ \\
\hline Normatif & 0.794 & 0,572 & $(0,891)$ & & 0,382 & $-0,307$ & $-0,318$ \\
\hline Berkelanjutan & 0.693 & 0,534 & 0,382 & & $0,832)$ & $-0,379$ & $-0,380$ \\
\hline Individu & 0.666 & $-0,400$ & $-0,307$ & & $-0,379$ & $(0,816)$ & 0,810 \\
\hline Organisasi & 0.601 & $-0,378$ & $-0,318$ & & $-0,380$ & 0,810 & $(0,775)$ \\
\hline
\end{tabular}

Sumber : Hasil Olahan Data (2017) 
Nilai tersebut menunjukkan bahwa variasi komitmen organisasi yang dijelaskan oleh iklim etis dan spiritualitas di tempat kerja sebesar $38,4 \%$, sedangkan sisanya dijelaskan oleh variabel lain. Nilai $\mathrm{R}^{2}$ untuk variabel perilaku menyimpang adalah
0,245. Nilai tersebut menunjukkan bahwa variasi perilaku menyimpang yang dijelaskan oleh iklim etis, spiritualitas di tempat kerja dan komitmen organisasi sebesar 24,5\%, sedangkan sisanya dijelaskan oleh variabel lain.

Tabel 4. Hasil Pengukuran R-Square

\begin{tabular}{lc}
\hline \multicolumn{1}{c}{ Variabel } & $\mathrm{R}^{2}$ \\
\hline Iklim Etis & - \\
Spiritual & 0,269 \\
Komitmen & 0,384 \\
Perilaku Menyimpang & 0,245 \\
\hline
\end{tabular}

Sumber : Hasil Olahan Data (2017)

Hair et.al (2014) menyatakan bahwa secara umum koefisien determinasi tergolong rendah jika bernilai 0,20, sementara pada hasil model ini kedua koefisien bernilai lebih dari 0,20. Sehingga berdasarkan hasil ini kecocokan model sudah tergolong baik. Menghitung kecocokan model dapat dilakukan dengan formula berikut :

$\mathrm{R}_{\mathrm{m}}^{2}=1-\left(1-\mathrm{R}_{1}^{2}\right) \ldots\left(1-\mathrm{R}_{\mathrm{n}}{ }^{2}\right)$

$\mathrm{R}_{\mathrm{m}}^{2}=1-(1-0,269)(1-0,384)(1-$

$0,245)$

$R_{m^{2}}=1-0,340$

$\mathrm{R}_{\mathrm{m}}^{2}=0,660$

Hasil penghitungan

menunjukkan nilai $\mathrm{R}_{\mathrm{m}}^{2}$ inner model sebesar 0,660 yang berarti model penelitian ini memiliki kecocokan model yang tinggi. Ketepatan model sebesar 66,0\% menerangkan bahwa kontribusi model untuk menjelaskan hubungan struktural dari kelima variabel yang diteliti adalah sebesar $66,0 \%$ dan sisanya dijelaskan oleh variabel lain yang tidak terlibat dalam model.

\section{Pengujian Model Struktural (Inner Model)}

Hasil pengujian model struktural (inner model) dapat dilihat pada Rsquare $\left(R^{2}\right)$ pada setiap konstruk endogen (spiritual, komitmen organisasi dan perilaku menyimpang), nilai koefisien jalur, nilai $\mathrm{t}$ dan nilai $\mathrm{p}$ tiap hubungan path antarkonstruk. 
Tabel 5. Hasil Pengujian Koefisien Jalur Pada Inner Model

\begin{tabular}{lccc}
\hline Hubungan & $\begin{array}{c}\text { Koefisien } \\
\text { jalur }\end{array}$ & $\begin{array}{c}\text { Deviasi } \\
\text { Standar }\end{array}$ & $\mathrm{P}$ \\
\hline Iklim Etis --> Spiritual & 0,518 & 0,087 & 0,000 \\
Iklim Etis --> Komitmen Organisasi & 0,312 & 0,083 & 0,000 \\
Iklim Etis --> Perilaku Menyimpang & $-0,168$ & 0,068 & 0,007 \\
Spiritual --> Perilaku Menyimpang & $-0,057$ & 0,065 & 0,190 \\
Komitmen --> Perilaku Menyimpang & $-0,348$ & 0,065 & 0,000 \\
\hline
\end{tabular}

Sumber : Hasil Olahan Data (2017)

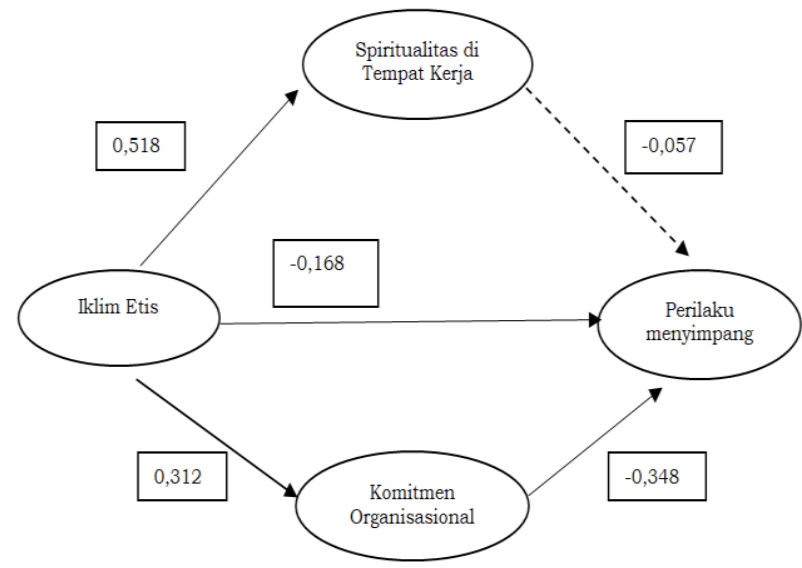

Gambar 1. Inner Model

Sumber: Hasil Olahan Data (2017)

Interpretasi dari tabel dan gambar tersebut yaitu hubungan antar variabel yang dijelaskan sebagai berikut:

1) Iklim etis terhadap perilaku menyimpang mempunyai koefisien dengan arah negatif. Hasilperhitungan menunjukkan bahwa koefisien jalur sebesar $0,168 \quad(p<0,05) \quad$ memberikan keputusan bahwa iklim etis berpengaruh signifikan terhadap perilaku menyimpang.

Dengan demikian mendukung Hipotesis $1(\mathrm{H} 1)$ yang menyatakan bahwa iklim etis berpengaruh signifikan negatif terhadap perilaku menyimpang

2) Iklim etis terhadap spiritualitas di tempat kerja mempunyai koefisien dengan arah positif.Hasil perhitungan menunjukkan bahwa koefisien jalur sebesar $0,518(\mathrm{p}<0,05) \quad$ memberikan keputusan bahwa iklim etis berpengaruh signifikan terhadap spiritualitas di tempat kerja.

Dengan demikian mendukung Hipotesis 2 (H2) yang menyatakan bahwa iklim etis berpengaruh signifikan negatif terhadap perilaku menyimpang

3) Spiritualitas di tempat kerja terhadap perilaku menyimpang mempunyai koefisien dengan arah negatif.Hasilperhitungan

menunjukkan bahwa koefisien jalur sebesar $-0,057 \quad(p>0,05)$ memberikan keputusan bahwa spiritualitas di tempat kerja berpengaruh tidak signifikan terhadap perilaku menyimpang.

Dengan demikian menolak Hipotesis 3 (H3) yang menyatakan 
bahwa iklim etis berpengaruh signifikan terhadap perilaku menyimpang

4) Iklim etis terhadap komitmen organisasional mempunyai koefisien dengan arah positif. Hasilperhitungan menunjukkan bahwa koefisien jalur sebesar $0,312 \quad(p<0,05) \quad$ memberikan keputusan bahwa iklim etis berpengaruh signifikan terhadap komitmen organisasi..

Dengan demikian mendukung Hipotesis 5 (H5) yang menyatakan bahwa iklim etis berpengaruh signifikan terhadap komitmen organisasional

5) Komitmen organisasi terhadap perilaku menyimpang mempunyai koefisien dengan arah negatif. Hasil perhitungan menunjukkan bahwa koefisien jalur sebesar -
0,348

$(\mathrm{p}<0,05)$ memberikan keputusan bahwa komitmen organisasi berpengaruh signifikan terhadap perilaku menyimpang. Hasil analisis ini menyatakan bahwa komitmen organisasi yang kuat bisa menghambat perilaku menyimpang

Dengan demikian mendukung Hipotesis 6 (H6) yang menyatakan bahwa komitmen organisasi berpengaruh signifikan terhadap perilakui menyimpang.

\section{Pengujian Jalur Mediasi (Pengaruh Tidak Langsung)}

Untuk mengukur tingkat signifikansi pengaruh tidak langsung melalui mediasi, digunakan pendekatan Sobel Test.

Tabel 6. Hasil Sobel Test Pengujian Mediasi

\begin{tabular}{lccc}
\hline \multicolumn{1}{c}{ Hubungan } & $\begin{array}{c}\text { Koefisien } \\
\text { jalur }\end{array}$ & $\begin{array}{c}\text { Deviasi } \\
\text { Standar }\end{array}$ & P \\
\hline $\begin{array}{l}\text { Mediasi spiritualitas pada hubungan iklim } \\
\text { etis dan perilaku menyimpang }\end{array}$ & & & \\
Iklim Etis --> Spirituala & 0,518 & 0,087 & 0,000 \\
$\begin{array}{l}\text { Spiritual --> Perilaku Menyimpang } \\
\text { Iklim Etis --> Spiritual--> Perilaku }\end{array}$ & $-0,057$ & 0,065 & 0,190 \\
Menyimpangab & $-0,030$ & 0,034 & 0,379 \\
\hline Mediasi komitmen organisasi pada & & & \\
hubungan iklim etis dan perilaku & & & \\
menyimpang & 0,312 & 0,083 & 0,000 \\
Iklim Etis --> Komitmen Organisasia & $-0,348$ & 0,065 & 0,000 \\
Komitmen --> Perilaku Menyimpangb & $-0,109$ & 0,035 & 0,002 \\
Iklim Etis --> Komitmen Organisasi--> & & & \\
Perilaku Menyimpangab & & &
\end{tabular}


Berdasarkan hasil uji Sobel untuk pengaruh tidak langsung dengan mediasi, maka terlihat bahwa untuk untuk jalur spirutualitas di tempat kerja sebagai mediasi terhadap iklim etis dan perilaku menyimpang, nilai $\mathrm{p}>0,05$ adalah tidak signifikan. Dengan demikian menolak Hipotesis 4 (H4) yang menyatakan bahwa spiritualitas di tempat kerja memediasi pengaruh iklim etis terhadap perilaku menyimpang

Sedangkan untuk jalur komitmen organisasi sebagai mediasi terhadap iklim etis dan komitmen organisasi, nilai $\mathrm{p}<0,05$ adalah signifikan. Dengan demikian mendukung Hipotesis 7 (H7) yang menyatakan bahwa komitmen organisasi memediasi pengaruh iklim etis terhadap perilaku menyimpang

\section{KESIMPULAN IMPLIKASI DAN KETERBATASAN PENELITIAN}

Berdasarkan hasil analisa data dan pembahasan diatas dapat disimpulkan bahwa; (1) Iklim etis berpengaruh signifikan terhadap perilaku menyimpang, (2). Iklim etis berpengaruh terhadap spiritualitas di tempat kerja, (3) Spiritualitas berpengaruh terhadap perilaku menyimpang, (4) Iklim etis berpengaruh terhadap perilaku menyimpang dengan dimediasi oleh spiritualitas di tempat kerja (5) iklim etis berpengaruh terhadap komitmen organisasional, (6) Komitmen berpengaruh terhadap perilaku menyimpang, (7) Iklim etis berpengaruh terhadap perilaku menyimpang dengan dimediasi oleh komitmen organisasional. Implikasi dari penelitian ini merupakan kontribusi bagi pegawai pemerintah daerah Provinsi Maluku sebagai pelayan publik untuk dapat menerapkan nilai-nilai iklim etis, dan komitmen organisasi secara baik seta dalam mengurangi perilaku menyimpang. Saran kedepan hendaklah nilai-nilai itu semakin ditingkatkan terutama nilai spiritualitas di tempat kerja. Saran bagi peneliti lainnya adalah mengkaji lebih mendalam lagi faktor-faktor lain yang berpengaruh terhadap perilaku menyimpang seperti kepemimpinan, dan kepuasan kerja.

\section{REFERENSI}

Adejoh MA and Adejoh LL, 2013. Handling negative deviant behaviour of front-line employees in service organisations. Int $J$ Cur Res Rev, Feb 2013 / Vol 05 (04

Appelbaum, Deguire and Lay. 2005. The relathionship of Ethical Climate to Deviant Workplace Behavior. Matthieu Corporate Governance,5,4.

Appelbaum SH, Iaconi GD and Matousek A, 2007. Positive and 
negative deviant workplacebehaviors: causes, impacts, and solutions. Corporate Governance. Vol. 7 No. 5 2007, pp. 586-598.

Aquino, K., Galperin, B.L. and Bennett, R.J, 2006. Social status and aggressiveness as moderators of the relationship between interactional justice and workplace deviance", Journal of Applied Social Psychology, Vol. 34 No. 5, pp. 1001-29.

Bennett RJ and Robinson SL, 2000. Development of a Measure of Workplace Deviance. Journal of Applied Psychology 2000, Vol. 85, No. 3, 349-360

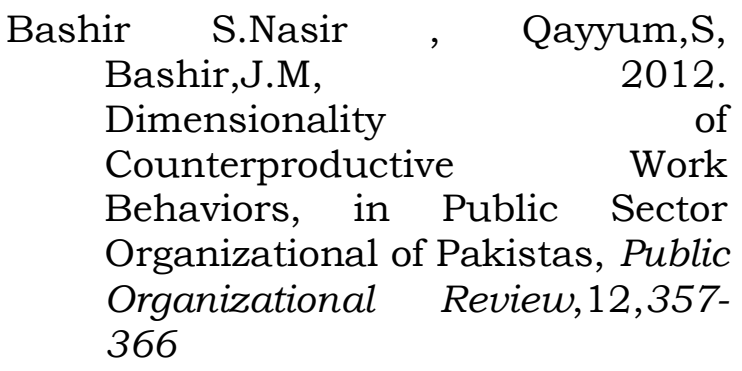

Berry, C. M., Ones, D. S., \&Sackett, P. $\mathrm{R}, 2007$. Interpersonal deviance, organizational deviance, and their common correlates: A review and meta-analysis. Journal of Applied Psychology 410-424.

Bollin and Heatherly, 2001. Predictor of employee deviance : The relationship between bad attitude and bad behavior. Journal of Business and Pshycology.

Chen LL, Fah BCY, Jin TC, 2015. Perceived Organizational Support and Workplace Deviance in the Voluntary Sector. Procedia Economics and Finance 35 ( 2016 ) $468-475$.

Fagbohungbe BO, Akinbode GA, Ayodeji F, 2012.Organizational
Determinants of Workplace Deviant Behaviours: An Empirical Analysis in Nigeria. International Journal of Business and Management Vol. 7, No. 5.

Fernandez S and Tima Moldogaziev, 2011. Empowering Public Sector Employees to Improve Performance: Does It Work? The American Review of Public Administration 41(1)23-47. Sagepub.com/journalsPermissio ns.nav DOI: 10.1177/0275074009355943 http://arp.sagepub.com

Ferris DL, Brown DJ and Heller D, 2009. Organizational supports and organizational deviance: The mediating roleof organizationbased self-esteem. Organizational Behavior and Human Decision Processes 108 (2009) 279-286

Ghozali, 2008. SEM Metode Alternatif dengan PLS. Penerbit Badan Penerbit Universitas Diponegoro ISNB : 979.704.250.9

Hair, J.F., Tomas, G., Ringle, C. M., and Sarstedt, M, 2014. A Primer on Partial Least Squares Structural Equation Modeling (PLS-SEM), Sage Publications, California.

Hair J.F., Marko Sarstedt. Lucas H., Volker G.K, 2014, Partial least Squares Structural Equating Modeling (PLS-SEM) : An Emerging Toll in Business Researc. European Business Review Vol 26 No 2.

Harper, D, 1990. Spotlight Abuse Save Profits. Industrial Distribution, 79, 47-51

Hershcovis MS, Turner N, Barling J, Arnold KA, Dupre KE, Inness M, LeBlanc MM and Sivanathan N, 2007. Predicting Workplace 
Aggression: A Meta-Analysis. Journal of Applied Psychology Vol. 92, No. 1, 228-238

Lee, K., \& Allen, N. J, 2002. Organizational citizenship behavior and workplace deviance: The role of affect and cognitions. Journal of Applied Psychology, 87, 131-142.

Luthans, 2006. Organizational Commitment : Analysis of antecedents. Human Relation Vol 40 No 4. Pp 219-236.

Milliman, J., Czaplewski, A. J., \& Ferguson, J, 2006. Workplace spirituality and employee work attitudes: An exploratory empirical assessment. Journal of Organizational

Change Management, 16(4), 426-447. http://dx.doi.org/10.1108/0953 $\underline{4810310484172}$

Moinihan and Pandey, 2007. Finding Workable Levers Over Work Motivation Comparing Job Satisfaction, Job Involvement, and Organizational Commitment. Administration and Society

Muafi, J. 2011, Causes \& consequences of deviant workplace behaviour. International Journal of Innovation, Management and Technology, 2 (2), 123 - 126.

Olabimitan and Alausa, 2014. Psychological Factors predicting workplace deviance behavior among nurses in the public health sector in Lagos. Nigerian Journal of Applied Behavioural Sciences, 2 (June) 137-152

$\begin{array}{lcr}\text { Pradiansyah, } & \text { Arvan. } & \text { 2007, } \\ \text { Spiritualitas } & \text { Dalam } & \text { Bisnis: } \\ \text { Lahirnya } & \text { Generasi } & \text { Ketiga. } \\ \text { Jakarta: } & \text { Swasembada } & \text { No. } \\ \text { 05/XXIII/1-14 } & \text { Maret 2007, hal } \\ \text { 63-64 } & & \end{array}$

Robbins S.P 2015, Handbook Organizational Behavior $16^{\text {th }}$ ed. Publish by Pearson. Inc.

Sauber, I. 2013. Spirit in the Workplace. Diunduh dari http:/ / www.byregion.net/ articleshealers/Spirit_in_Workplace.htm 1.

Thau S,Bennett RJ, Mitchell MS, Marrs MB, 2009. How management style moderates the relationship between abusivesupervision and workplace deviance: An uncertainty management theoryperspective.

Organizational Behavior and Human Decision Processes 108 (2009) 79-92

Thompso, 2000. Can you train people to be a spiritual ? Training and Developmenty Vol 54 No 12,pp 18-19

Undang-Undang Nomor 23 Tahun 2014 tentang Otonomi Daerah

Undang- Undang Nomor 42 tahun 2004 tentang Kode Etik Pegawai negeri Sipil

Vantilborgh T, Bidee J, Pepermans R, Willems J, Huybrechts G, and Jegers M, 2012. Volunteers Psychological Contracts: Extending Traditional Views. Nonprofit and Voluntary Sector Quarterly41(6) 1072-1091

Wong A.. C Tong, 2014. Evaluation of Organizational Commitment Models and Their Components in Asian Cities. Internasional Journal of Human Resources Studies

Yoon and Thyye, 2002. A Dual Process Model of Organizational 
Commitment. Work and Occupation

Yousef, 2002. Job satisfaction as a mediator of the relationship between role stressors and organizational commitment A study from an Arabic cultural perspective. Journal of Managerial Pshycology,Vol 17 No 4,pp 250-266
Zohar, D. \& Marshall, I, 2000. SQ: Spiritual Intelligence: the ultimate intelligence. London: Bloomsbury

Zribi H and Souaï S, 2013. Deviant Behaviors in Response to Organizational Injustice: Mediator Test for Psychological Contract Breach-The Case of Tunisia. Journal of Business Studies Quarterly 2013, Volume 4, Number 4, 